\title{
Irrigation modeling in a pear orchard
}

\author{
Nagy, A. ${ }^{1}$, Tamás, J. ${ }^{1}$, Fórián, T. ${ }^{1}$, Nyéki, J. ${ }^{2}$, Soltész, M. ${ }^{2} \&$ Szabó, Z. ${ }^{2}$ \\ ${ }^{1}$ University of Debrecen, Centre of Agricultural Sciences and Engineering, Faculty of Agronomy, Department \\ of Water and Environmental Management, H-4032 Debrecen, Böszörményi 138, Hungary, \\ tamas@gisserver1.date.hu \\ ${ }^{2}$ University of Debrecen, Centre of Agricultural Sciences and Engineering, Institute for Research and \\ Development
}

\begin{abstract}
Summary: The pear has large water requirement, therefore the planting of high density and grass covered pear orchards are needed irrigation conditions in Hungary. Drip irrigation spread in the orchards is due to the 90-95\% of water use efficiency. One of the key role of irrigation is the proper determination of evapotranspiration and crop coefficients. As there is a considerable lack of information for different crops or fruits the Penman-Monteith method is used for the estimation of evapotranspiration, using CROPWAT 8.0. The research field was the genetic collection of pear at Újfehértó, in Hungary, which is situated in Nyírség meso-region. Our aim was to establish drip irrigation at this site. Based on the results of CROPWAT irrigation model the mean amount of the total gross irrigation is between 230-270 mm, within 3 irrigation interval regarding climatic and rainfall data of the last 10 years. In 2009, due to heavy drought, the total gross irrigation was 355,4 mm/year on sandy soil calculating with $45 \%$ total available water depletion in 5 irrigation interval. The sizing of the irrigation system was set to the maximum $0.551 / \mathrm{s} / \mathrm{ha}$, which is $6.3 \mathrm{l} / \mathrm{tree} / \mathrm{h}$. $6.3 \mathrm{l} / \mathrm{tree} / \mathrm{h}$ can be carried out with a drip emitter having $16 \mathrm{~mm}$ wing lines diameter, $4 \mathrm{l} / \mathrm{h}$ water flow at 3 atm pressure.
\end{abstract}

Key words: drip irrigation, pear orchard, CROPWAT model

\section{Introduction}

The limited water resources and the increasing frequency of extreme hydrological events (floods, water-logging, overmoistening and drought) due to the high territorial and temporal variability of atmospheric precipitation; the heterogeneous (micro) relief; and the unfavorable physical/hydro physical characteristics of soils are pressing to improve agricultural water use efficiency and necessitates an efficient control of soil moisture regime in the Carpathian Basin (Pálfai, 2000; Várallyay, 1989). It can be forecast with high probability that in future water will be the determining (hopefully not limiting) factor of food security and environmental safety in the Carpathian Basin (Somlyódy, 2000; Várallyay, 2002). The extremities in the amount and distribution of rain are showing an increasing tendency in Hungary, which often causes problems in crop production (Várallyay, 2005).

Hungary has favourable agro ecological potential for pomaceous fruit production. Nowadays one of the novel and widespread achievement of pear production is the intensive pear plantations with high tree density (Takács 2009; Soltész \& Szabó 1998; Hrotkó 1999). The pear has large water requirement, therefore the planting of high density and grass covered pear orchards are needed irrigation conditions in Hungary. For example, the water requirements of pear 'Williams' were 470-480 mm for the whole growing season on loamy sand soil. The water deficiency is particularly the low soil moisture content diminish the fruit quality during fruit growth. The low limit of optimal soil moisture is at $50-60 \%$ of field water capacity, below that the pear yield is significantly decreasing (Bosnjak et al., 1997). The average daily water use of pear orchard grown under good water supply varied between 3 and $5 \mathrm{~mm}$ however it could exceed $7 \mathrm{~mm} /$ day on warm days (Papp, 2000). Despite this fact, several orchards haven't got any irrigation, or its irrigation system is not appropriate in the used irrigation technology point of view. In many cases precision water and energy safe irrigation can not be established due to the lack information of water capacities of the soil, and the time-changing dynamic water demand of the plant. Consequently, the role of the detailed and proper information in irrigation will be one of the key issues of fruit production.

Drip irrigation spread in the orchards is due to the $90-95 \%$ of water use efficiency (Tóth, 1996). The drip irrigation is good delivery system because it allows doing the agricultural procedures between the rows in the orchards and providing the water and nutrient used by fertigation to reach the high density root zone. The wing lines running from the head line are set up fixed on the stay system of on the soil in the tree rows and their emitters output 1-5 1/hour. The distances between emitters on the hose are chosen in accordance with planting of the trees in the rows (Nemeskéri, 2009). This type of irrigation has no influence on the air humidity during hot days.

\section{Materials and methods}

The research field was the genetic collection of pear at Újfehértó, in Hungary, which is situated in Nyírség meso- 
region. The area of the site is 2,74 ha, with 1660 planting density tree/ha possible spaces of pear trees. The physical characteristic of the soil is sandy and the pear orchard is not irrigated. The irrigation modeling was set by CROPWAT 8.0 based on the climatic, crop and soil data inputs of the last 10 years (Figure 1.). Special attention was taken on 2009, because of the long term drought. Climatic data and rain fall data was obtained from the meteorological station next to the pear orchard. One of the key role of irrigation is the proper determination of evapotranspiration. Using the calculation of water balance regime evapotranspiration can be determined indirectly with the following equation, based on FAO 56 (Allen et al. 1998):

$$
\mathrm{ET}_{\mathrm{c}, \mathrm{i}}=\mathrm{D}_{\mathrm{r}, \mathrm{i}}-\mathrm{D}_{\mathrm{r}, \mathrm{i}-1}+(\mathrm{P}-\mathrm{RO})_{\mathrm{i}}+\mathrm{I}_{\mathrm{i}}+\mathrm{CR}_{\mathrm{i}}-\mathrm{DP}_{\mathrm{i}}
$$

where

$\mathrm{ET}_{\mathrm{c}, \mathrm{i}}$ crop evapotranspiration on day i [mm],

$\mathrm{D}_{\mathrm{r}, \mathrm{i}}$ root zone depletion at the end of day $\mathrm{i}[\mathrm{mm}]$,

$\mathrm{D}_{\mathrm{r}, \mathrm{i}-1}$ water content in the root zone at the end of the previous day, i-1 [mm],

$\mathrm{P}_{\mathrm{i}} \quad$ precipitation on day $\mathrm{i}[\mathrm{mm}]$,

$\mathrm{RO}_{\mathrm{i}}$ runoff from the soil surface on day $\mathrm{i}[\mathrm{mm}]$,

$\mathrm{I}_{\mathrm{i}}$ net irrigation depth on day $\mathrm{i}$ that infiltrates the soil [mm],

$\mathrm{CR}_{\mathrm{i}}$ capillary rise from the groundwater table on day $\mathrm{i}$ [mm],

$\mathrm{DP}_{\mathrm{i}}$ water loss out of the root zone by deep percolation on day $\mathrm{i}[\mathrm{mm}]$.

Crop and fruit evapotranspiration can also be calculated from climatic data and by integrating directly the crop or fruit resistance, albedo and air resistance factors in the Penman-Monteith approach, i.e., ET $\mathrm{E}_{\mathrm{o}}$. As there is a considerable lack of information for different crops or fruits the Penman-Monteith method is used for the estimation of the standard reference crop or fruit to determine its evapotranspiration rate. From the original Penman-Monteith equation and the equations of the aerodynamic and surface resistance, the FAO 56 Penman-Monteith method to estimate $\mathrm{ET}_{\mathrm{O}}$ is expressed as:

$$
E T_{0}=\frac{0.408 \Delta\left(R_{n}-G\right)+\gamma \frac{900}{T+273} u_{2}\left(e_{s}-e_{a}\right)}{\Delta+\gamma\left(1+0.34 u_{2}\right)}
$$

where:

$\mathrm{ET}_{\mathrm{o}}$ reference evapotranspiration $\left[\mathrm{mm} \mathrm{day}^{-1}\right]$,

$R_{n}$ net radiation at the crop surface $\left[\mathrm{MJ} \mathrm{m}^{-2}\right.$ day $\left.^{-1}\right]$,

$\mathrm{G}$ soil heat flux density $\left[\mathrm{MJ} \mathrm{m}^{-2}\right.$ day $\left.^{-1}\right]$,

$\mathrm{T}$ mean daily air temperature at $2 \mathrm{~m}$ height $\left[{ }^{\circ} \mathrm{C}\right]$,

$\mathrm{u}_{2}$ wind speed at $2 \mathrm{~m}$ height $\left[\mathrm{m} \mathrm{s}^{-1}\right]$,

$\mathrm{e}_{\mathrm{s}} \quad$ saturation vapour pressure $[\mathrm{kPa}]$,

$\mathrm{e}_{\mathrm{a}}$ actual vapour pressure $[\mathrm{kPa}]$,

$\mathrm{e}_{\mathrm{s}}-$ ea saturation vapour pressure deficit $[\mathrm{kPa}]$,

D slope vapour pressure curve $\left[\mathrm{kPa}^{\circ} \mathrm{C}^{-1}\right]$,

$\gamma$ psychrometric constant $\left[\mathrm{kPa}^{\circ} \mathrm{C}^{-1}\right]$.
Differences in leaf anatomy, stomatal characteristics, aerodynamic properties and even albedo cause the crop or fruit evapotranspiration to differ from the reference crop or fruit evapotranspiration under the same climatic conditions. Due to variations in the crop, and in fruits as well, characteristics throughout its growing season, $\mathrm{K}_{\mathrm{c}}$ for a given crop or fruit changes from sowing till harvest. In the crop coefficient approach the crop or fruit evapotranspiration, $\mathrm{ET}_{\mathrm{c}}$, is calculated by multiplying the reference crop or fruit evapotranspiration, $\mathrm{ET}_{\mathrm{o}}$, by a crop coefficient, $\mathrm{K}_{\mathrm{c}}$ :

$$
\mathrm{ET}_{\mathrm{c}}=\mathrm{K}_{\mathrm{c}} * \mathrm{ET}_{\mathrm{o}}
$$

where

$\mathrm{ET}_{\mathrm{c}}$ crop evapotranspiration $\left[\mathrm{mm} \mathrm{d}^{-1}\right]$,

$\mathrm{K}_{\mathrm{c}}$ crop coefficient [dimensionless],

$\mathrm{ET}_{\mathrm{o}}$ reference crop evapotranspiration $\left[\mathrm{mm} \mathrm{d}^{-1}\right]$.

Crop coefficient is computed for the following crop growing stages:

- initial stage,

- crop development stage,

- mid-season,

- late season.

The value of the crop coefficient is between $0.3-1.2$ depending on crop varieties, so its average estimation error can reach the 200-300\%. Based on the FAO 56 and FAO 24 irrigation and water papers the Kc values of a pear orchard without ground cover are between 0.4 in initial stage, 0.9 in mid- and 0.65 in late season (Dorenbos \& Pruitt, 1977; Dorenbos \& Kassam, 1979; Allen et al. 1998). Girona et al. (2004) is measured $0.85 \mathrm{~K}_{\mathrm{c}}$ of pears in lysimeters, although, in the case of an another lysimeter study in Portugal, the mean $\mathrm{K}_{\mathrm{c}}$ of pear (for the mid-season stage) was 0.5 , below the tabled $\mathrm{K}_{\mathrm{c}}$ for pear orchards with no ground cover (0.95) or with active ground cover (1.2), confirming the need for adjusting published values for local conditions (Conceição et al., 2008). In our studies, crop coefficients were set based on the recommendation of Irrigation and Drainage FAO 56 paper, without ground cover crop (weed free cultivated.

Since the value of the actual crop water requirement based on model sensitivity analyses depends on the actual value of $\mathrm{K}_{\mathrm{c}}$ significantly, the error propagation influences the reliability of the whole model. One of the aims of our further researches is the rise of the accuracy of this parameter using remote sensing data source.

Besides evapotranspiration, the amount of precipitation is also determine the amount or irrigation water. However, the efficiency of the total precipitation is never $100 \%$, therefore the effective rain should be calculated. All rainfall options refer to the calculation of the effective rainfall based on the actual rainfall data. The options are:

Fixed percentage: The fixed percentage is to be given by the user to account for the losses due to runoff and deep percolation. Effective rainfall is a fixed percentage of actual rainfall. 


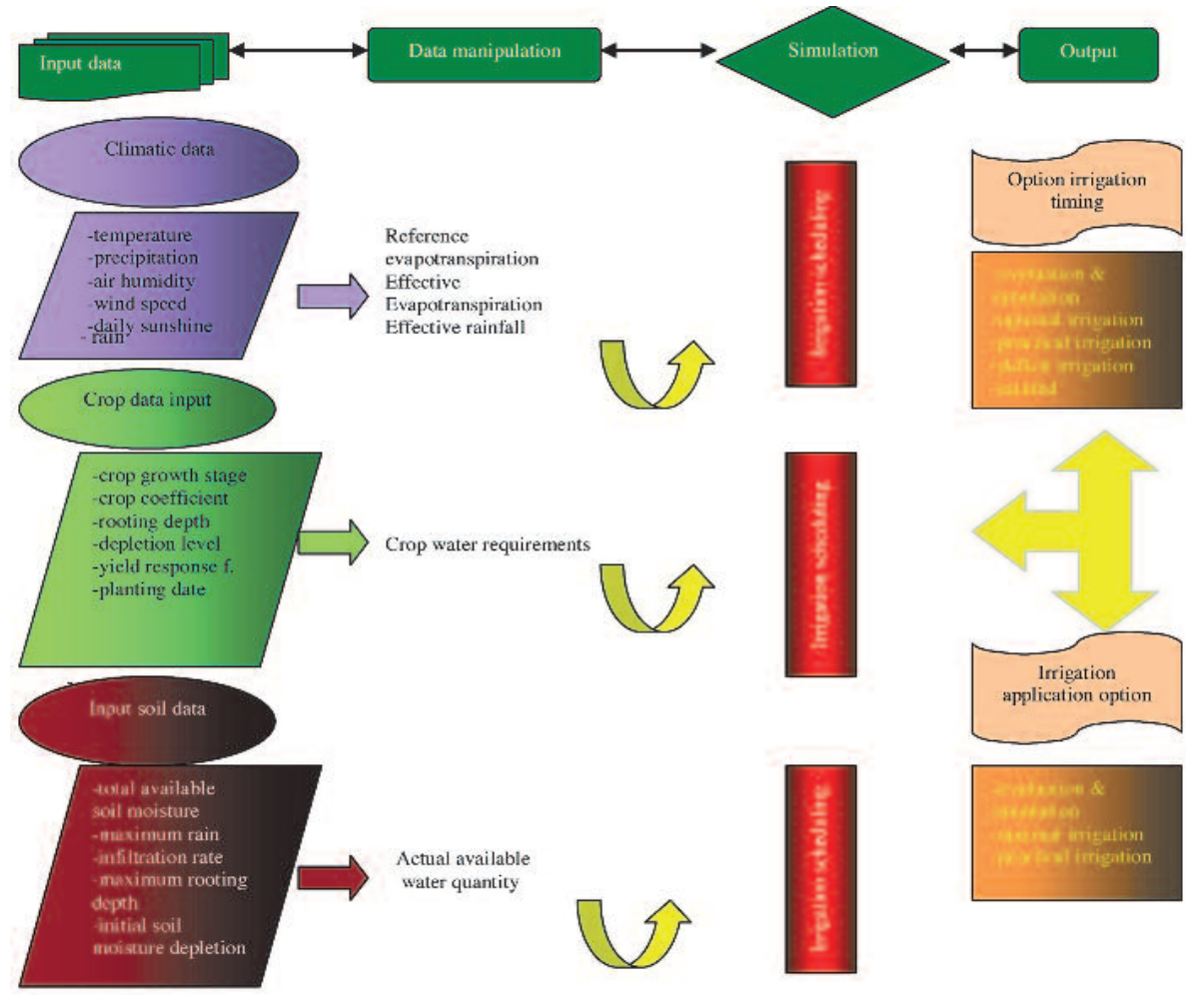

Figure 1. CROPWAT 8.0 irrigation model parameters

Dependable rainfall (FAO/AGLW formula): Based on an analysis carried out for different arid and sub-humid climates, an empirical formula was developed in the Water Service of FAO to estimate dependable rainfall, the combined effect of dependable rainfall ( $80 \%$ probability of exceedance) and estimated losses due to Runoff (RO) and Deep Percolation (DP). This formula may be used for design purposes where $80 \%$ probability of exceedance is required. Calculation according to (monthly step):

$$
\begin{aligned}
& \mathrm{P}_{\text {eff }}=0.6 * \mathrm{P}-10 \text { for } \mathrm{P}_{\text {month }}<=70 \mathrm{~mm} ; \\
& \mathrm{P}_{\text {eff }}=0.8 * \mathrm{P}-24 \text { for } \mathrm{P}_{\text {month }}>70 \mathrm{~mm}
\end{aligned}
$$

Empirical formula: Same formula as for Dependable rainfall but with the possibility to change the parameters, which may be determined from an analysis of local climatic records (monthly step):

$$
\begin{aligned}
& \mathrm{P}_{\text {eff }}=\mathrm{a} * \mathrm{P}_{\text {month }}-\mathrm{b} \text { for } \mathrm{P}_{\text {month }}<=\mathrm{z} \mathrm{mm} ; \\
& \mathrm{P}_{\text {eff }}=\mathrm{c} * \mathrm{P}_{\text {month }}-\mathrm{d} \text { for } \mathrm{P}_{\text {month }}>\mathrm{z} \mathrm{mm}
\end{aligned}
$$

values for $\mathrm{a}, \mathrm{b}, \mathrm{c}, \mathrm{d}$ and $\mathrm{z}$ are correlation coefficients.

USDA Soil Conservation Service: Formula developed by USCS, where effective rainfall can be calculated according to (monthly step):

$$
\begin{aligned}
& \mathrm{P}_{\text {eff }}=\mathrm{P}_{\text {month }} *\left(125-0.2 * \mathrm{P}_{\text {month }}\right) / \\
& 125 \text { for } \mathrm{P}_{\text {month }}<=250 \mathrm{~mm} \\
& \mathrm{P}_{\text {eff }}=125+0.1 * \mathrm{P}_{\text {month }} \text { for } \mathrm{P}_{\text {month }}>250 \mathrm{~mm}
\end{aligned}
$$

Rooting depth of the pear trees were $1,2 \mathrm{~m}$, the crop height was $3 \mathrm{~m}$. Soil data was derived from field measurements, water depletion factor was set to 0,45 for pear orchard, based on the recommendation of Irrigation and Drainage FAO 56 paper.

\section{Results and discussion}

The hydrologic and climatic parameters were different from the mean values in 2009. The amount of the precipitation was less than the average, but its distribution was differed in time from the average values, which was very disadvantageous for pomaceous orchards. At the beginning of 2009 the precipitation had usual, adequate amount, similarly to a regular precipitation status at the end of winter. However, there was a severe drought in April and May. This deficiency was partly compensated in June, but there were also less precipitation than average causing severe drought in July and August (Figure 2).

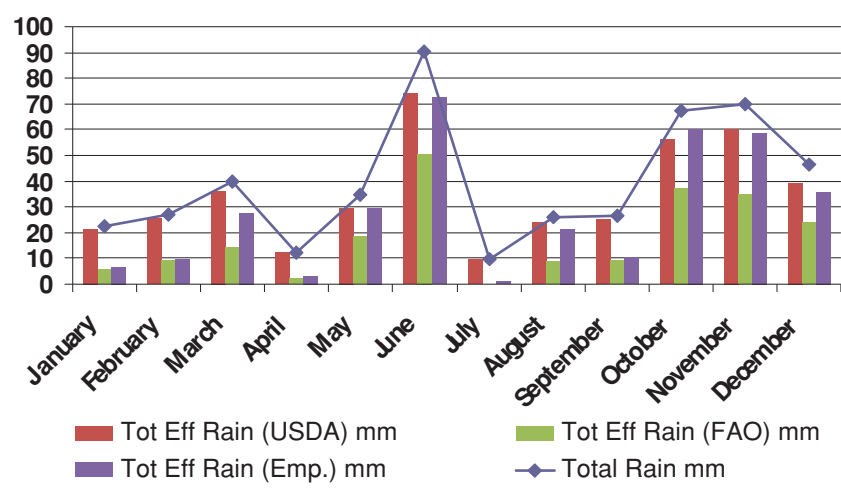

Figure 2. The amount of effective rain with different methods

There are several factors which influence unfavorably the efficiency of the precipitation, such as the most important runoff, deep percolation, lateral flow, evaporation. These related factors can be characterized with different dynamic both in spatially and in time, therefore several approximate methods are used to calculate the effective rain. In Újfehértó, the amount of the precipitation and effective rain were the followings in 2009 year: $472.9 \mathrm{~mm}$ total rain; $413.5 \mathrm{~mm}$ effective rain calculated with USDA method; $213.5 \mathrm{~mm}$ calculated with FAO method; $336.1 \mathrm{~mm}$ calculated with Empirical method. Since the examination site is flat and there were no measurements for interception, deep percolation and runoff, the FAO/AGLW formula was designed for arid climate, empirical method is for Mediterranean climate and USDA method is suitable for semihumid climate, USDA method was used to calculate the amount of the effective rain in our research. 
The determination of evapotranspiration is one of the most uncertain out of all agro hydrological factors. There are several method is known to calculate the potential evapotranspiration. In this research Penman-Monteith method was used (Figure 3.).

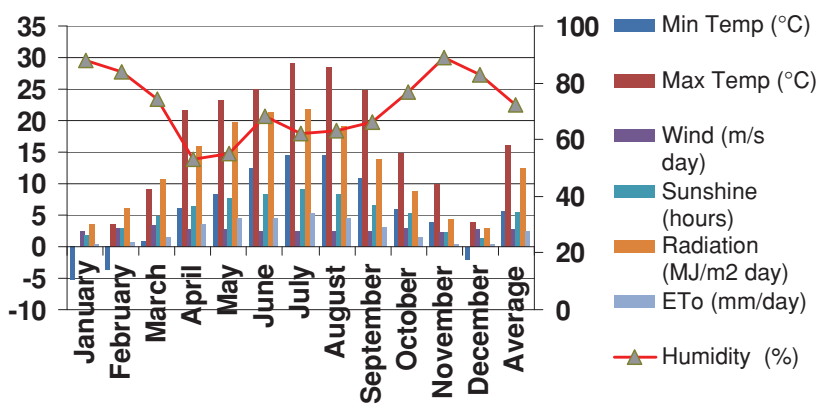

Figure 3. $\mathrm{ET}_{\mathrm{o}}$ changes in 2009

The relative humidity was below the critical $65 \%$ for 4 months, causing areal drought for pear orchard. Due to the low water capacity of sandy soil the water content decreased far below field water capacity, which often caused air drought between 11-15 o'clock in April, May, July and August, because of the low relative humidity (Figure 4.).

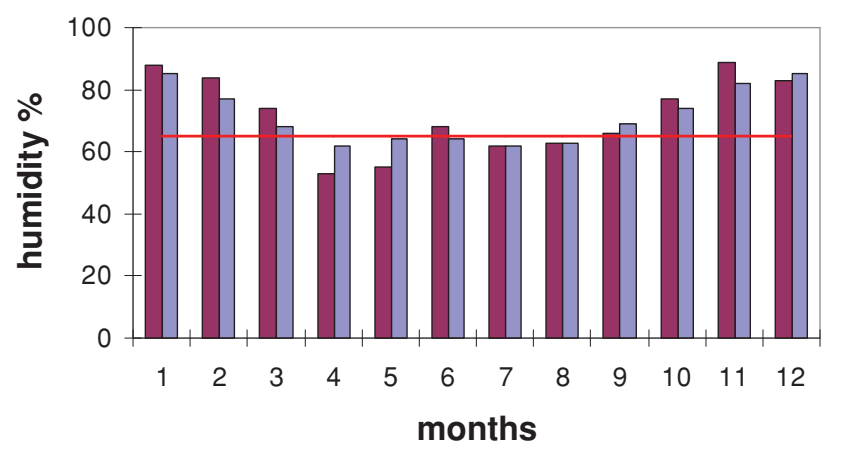

$2009 \% \square$ mean of 30 years - 65\% humidity $\%$

Figure 4. Air drought in 4 months in 2009

The irrigation water demands of both summer and autumn ripening pear varieties were calculated on sandy soil in Újfehértó. Based on the results of 2009, the CROPWAT model obviously shows, that a large amount of water should be irrigated, especially in summer in the case of both variety (Figure 5.), (Figure 6).

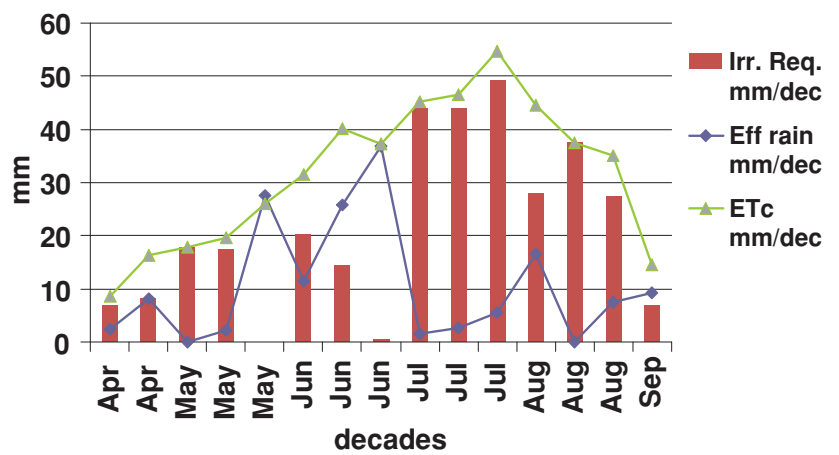

Figure 5. Irrigation water demand of summer ripening pear varieties on sandy soil

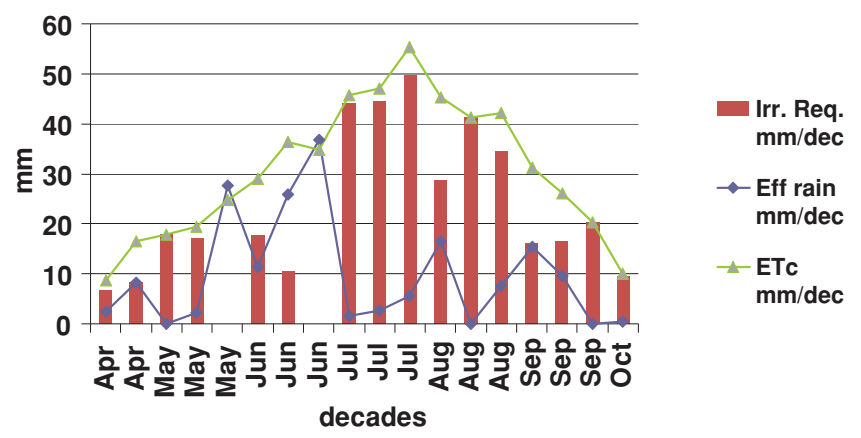

Figure 6. Irrigation water demand of autumn ripening pear varieties on sandy soil

Since autumn ripening pear varieties have greater water demand, the irrigation schedule was determined for this variety on sandy soil. Based on the irrigation schedules of the last 10 years the mean amount of the total gross irrigation is between 230-270 mm, within 3 irrigation interval (Table 1), although in 2009, due to heavy drought, the total gross irrigation was 355.4 $\mathrm{mm} /$ year on sandy soil calculating with $45 \%$ total available water depletion in 5 irrigation interval (Table2.).

Table 1. Irrigation schedule of pear orchard on sandy soil in 2002

\begin{tabular}{|l|c|c|c|c|c|c|c|}
\hline \multirow{2}{*}{ Date } & \multirow{2}{*}{ Day } & \multirow{2}{*}{ Stage } & Depl & Net Irr & Gr. Irr & Flow & Tree flow \\
\hline & & & $\mathbf{\%}$ & $\mathbf{M m}$ & $\mathbf{m m}$ & $\mathbf{1} / \mathbf{s} / \mathbf{h a}$ & $\mathbf{1} /$ tree/h \\
\hline 1 Jul & 78 & Dev & 47 & 69.6 & 73.26316 & 0.108712 & 1.29 \\
\hline 26 Jul & 103 & Mid & 46 & 68.6 & 72.21053 & 0.334308 & 3.97 \\
\hline 2 Sep & 141 & End & 45 & 68 & 71.57895 & 0.218016 & 2.59 \\
\hline 6 Oct & End & End & 6 & & & & \\
\hline
\end{tabular}

The Flow represents the continuous water discharge needed to satisfy pear orchard irrigation requirements over the irrigation interval period. It is expressed in litre per second per hectare and calculated converting the Gross irrigation depth into a permanent supply. Gross irrigation represents the water depth (expressed in $\mathrm{mm}$ ) applied to the field. Since the Irrigation efficiency is usually lower than $100 \%$, only a fraction of the Gross irrigation depth, that is, the Net irrigation depth, effectively reaches crop root zone. Although the drip irrigation can provide minimal water lost, its efficiency often exceeds $90-95 \%$. Therefore the calculated total gross irrigation value was calculated with $95 \%$ efficiency (Tóth, 1995). Tree flow is expressed in litre per hour per hectare for 12 hours' irrigation period a day. Area demand of a pear tree was $16 \mathrm{~m}^{2}$ based on the row spacing $(8 \mathrm{~m})$ and plant-to-plant distance $(2 \mathrm{~m})$.

Table 2. Irrigation schedule of pear orchard on sandy soil in 2009

\begin{tabular}{|l|c|c|c|c|c|c|c|}
\hline \multirow{2}{*}{ Date } & \multirow{2}{*}{ Day } & \multirow{2}{*}{ Stage } & Depl & Net Irr & Gr. Irr & Flow & Tree flow \\
\cline { 4 - 8 } & & & $\mathbf{\%}$ & $\mathbf{M m}$ & $\mathbf{m m}$ & $\mathbf{1 / s} / \mathbf{h a}$ & $\mathbf{1 / t r e e / h}$ \\
\hline 26 May & 42 & Dev & 45 & 61.1 & 64.3 & 0.18 & 2.11 \\
\hline 12 Jul & 89 & Mid & 47 & 70.3 & 74.0 & 0.18 & 2.16 \\
\hline 28 Jul & 105 & Mid & 46 & 69.6 & 73.3 & 0.53 & 6.29 \\
\hline 17. Aug & 125 & Mid & 46 & 69.3 & 72.9 & 0.42 & 5.02 \\
\hline 11 Sep & 150 & End & 45 & 67.3 & 70.8 & 0.33 & 3.89 \\
\hline 6 Oct & End & End & 30 & & & & \\
\hline
\end{tabular}


In 2002 and 2009 the amount of available water was moderate and very low. Considering $45 \%$ depletion, the water can only be supplied by irrigation to prevent pear orchard from yield deficiency. The water should be utilized in 3 (2002) or 5 (2009) irrigation periods in the dates given in Table 1 and table 2 . The sizing of the irrigation system was set to the maximum $0.55 \mathrm{l} / \mathrm{s} / \mathrm{ha}$, which is $6.3 \mathrm{l} /$ tree/h based on the irrigation schedule of 2009, as the most drought year of the last ten years. This amount should be utilized by drip emitters or microsprinklers. $6.3 \mathrm{l} / \mathrm{tree} / \mathrm{h}$ can be carried out with a drip emitter having $16 \mathrm{~mm}$ wing lines diameter, $4 \mathrm{l} / \mathrm{h}$ water flow at $3 \mathrm{~atm}$ pressure. The distance between the drip emitters is $2 \mathrm{~m}$, in accordance with the planting of trees. The 9 wing lines should be set up fix on the soil surface in each row with $300 \mathrm{~m}$ length. To support the adequate air humidity for the pear orchard, 2 1/tree/h can be irrigated with microspinklers, for example with a jet pulse emitters, set up below crown cloud. The increased air humidity can provide more effective yield safe, and decrease the evapotranspiration as well, to some extent.

\section{Acknowledgement}

This research was funded by NKTH OM-00042/2008, OM-00265/2008 and OM-00270/2008, GVOP 3.1.1-200405-0087/3, FVM31174/1/2008 projects.

\section{References}

Allen, R.G., Pereira, L.S., Raes, D. \& Smith, M. (1998): Crop evapotranspiration: Guidelines for computing crop requirements. Irrigation and Drainage Paper No. 56, FAO, Rome, Italy, 300.

Bosnjak, D., Gvozdenopvic, D. \& Moldovan, S. (1997): Water requirements of pear William grown on loamy sand soil. Acta Hort. 449: 133-138

Conceição, N., Paço, T.A., Silva, A.L. \& Ferreira, M.I. (2008): Crop coefficients for a pear orchard (Pyrus communis L.) obtained using Eddy covariance. Acta Hort. 792: 187-192.
Doorenbos, J. \& Kassam, A.H. (1979): Yield response to water. Irrigation and Drainage- Paper n. 33. FAO, Rome, Italy, 193 pp.

Doorenbos, J. \& Pruitt, W.O. (1977): Guidelines for Predicting Crop Water Requirements. Food and Agriculture Organisation of the United Nations. FAO Irrigation and Drainage Paper, 24: 143.

Girona, J., Marsal, J., Mata, M. \& del Campo, J. (2004): Pear crop coefficients obtained in a large weighing lysimeter. Acta Hort. 664: 277-281.

Hrotkó K. (1999): A gyümölcsfajták alanyai. 407-506. p. In: Hrotkó K. (Szerk.): Gyümölcsfaiskola. Mezőgazda Kiadó, Budapest.

Nemeskéri, E. (2009): Irrigatioin of pear (A review) International Horticultural Science, 15 (1-2): 65-73.

Pálfai, I. (Ed.) (2000): The role and significant of water in the Hungarian Plain. (In Hungarian) Nagyalföldi Alapítvány. Békéscsaba

Papp, J. (2000): A körteültetvények vízgazdálkodása és öntözése. 249-255. (In: Göndör J-né (szerk.): Körte) Mezőgazda Kiadó, Budapest

Soltész, M., Szabó, T. (1998): Alma. 119-155. p. In: Soltész, M. (Szerk.): Gyümölcsfajta-ismeret és -használat. Mezőgazdasági Kiadó, Budapest. 513 p.

Somlyódy, L. (2000): Strategy of Hungarian water management (In Hungarian). MTA Vízgazdálkodási Tudományos Kutatócsoportja, Budapest. 370. p.

Takács, F. (2009): Almaalanyok értékelése két művelési rendszerben a nyírségi termesztő körzetben. PhD-thesis Corvinus Egyetem, Budapest

Tóth, Á. (1995): Az esőszerü és mikroöntözés gyakorlata. KITE RT. Nádudvar.

Várallyay Gy. (1989): Soil water problems in Hungary. Agrokémia és Talajtan, 38: 577-595.

Várallyay Gy. (2002): The role of soil and soil management in drought mitigation . In: Proc. Int. Conf. On Drought Mitigation and Prevention of Land Desertification, Bled, Slovenia, April 21-25 2002. ICID-CIIC. (CD)

Várallyay Gy. (2005): Klímaváltozások lehetséges talajtani hatásai a Kisalföldön. "Agro-21” Füzetek, 43: 11-23. 